УДК 72. 012.8+ 747: 728.5

DOI: $10.30857 / 2617-$ 0272.2018 .1 .12 .
САФРОНОВА О. О.

elrossa@ukr.net

Київський національний університет технологій та дизайну

\section{ВПРОВАДЖЕННЯ В НАВЧАЛЬНИЙ ПРОЦЕС ПРИНЦИПІВ ЛЮДИНО-ОРІЕНТОВАНОГО ПІДХОДУ В ДИЗАЙНІ АРХІТЕКТУРНОГО СЕРЕДОВИЩА}

Мета. Виявлення сутності поняття людино-орієнтованого підходу в дизайні середовища в його сучасному розумінні і очінка практики його впровадження в навчальний прочес.

Методика. Використано методи: системного аналізу наукових публікацій за тематикою дослідження; порівняльного аналізу сучасних методик і методів дизайн-проектування, досвіду впровадження стратегій людино-орієнтованого підходу в навчальний прочес.

Результати. Проведений гносеологічний аналіз витоків людино-центричного підходу в дизайні, визначене поняття сучасних стратегій людино-орієнтованого дизайну в проектуванні середовища, надані рекомендації щодо впровадження сучасних стратегій дизайну в навчальний проиес.

Наукова новизна. Вперше поняття людино-оріснтованого підходу в дизайні середовища розглядається як стратегія дизайну, щчо має характерні ознаки і етапи.

Практична значимість. Надані пропозичії щзодо ефективного впровадження методів стратегії людино-оріснтованого дизайну в навчальний процес.

Ключові слова: людино-орієнтований підхід, навчальний процес, дизайн архітектурного середовища, дизайн-мислення, людино-орієнтований дизайн, емпатійний дизайн.

Вступ. Особливості становлення і трансформації освітніх програм дизайну середовища визначаються тими загальними тенденціями, що спостерігаються як в архітектурному проектуванні міського середовища, так і в промисловому дизайні. Декларується, що сьогодні ми маємо справу 3 новим поколінням методів дизайну, в основу яких положений людино-орієнтований i міждисциплінарний підхід, коли кожен об'єкт проектування може стати об'єктом дизайну, а сам дизайнер виступає як синтезатор знань [1].

Звідси і виникнення поряд 3 новими поняттями в проектуванні (наприклад, інклюзивний дизайн) стратегій та методів, які використовують i розкривають творчий потенціал не тільки дизайнера, а й усіх учасників процесу проектування: партисипативне проектування (архітектура); плейсмейкінг (placemaking); дизайн-мислення (Design Thinking) тощо.

Рефреймінг дизайн-освіти був започаткований і отримав розвиток в країнах, відомих своїми школами дизайну. Це перш за все, США, Італія, Англія, де змінились традиційні організаційні форми освіти, пов'язані 3 посиленням комунікаційної складової в дизайні, орієнтацією на учасників ринку - споживача i замовника. Зміни відбуваються на рівні трьох основних складових дизайн-освіти: методології проектування, що забезпечує онтологічні компетентності фахівців; способах інтеграції дизайну у виробничі процеси (маркетингові, менеджерські, комунікативні компетенції); інструментальній підготовці студентів, що базується, перш за все, на комп'ютерному моделюванні [2].

Особливу увагу в освітніх системах передових університетів світу сьогодні приділяють розвитку дизайн-мислення. $\mathrm{У}$ різних контекстах цей термін розуміють як: 1) творчу компетентність або креативність мислення [3]; 2) методику створення інновацій, що широко тиражується Школою Дизайну (D. School) університету м. Стенфорд (США), застосовну до всіх видів дизайну, в тому числі і до вирішення бізнес-завдань. Особливості останньої методики були розглянуті автором у роботі [4]. Ідея гуманізації, як створення дружнього для людини простору, є ключовою у рішенні завдань 3 архітектурного проектування і дизайну середовища. Так, за думкою видатного фінського архітектора, А. Аалто: «Справжня архітектура тільки там, де в

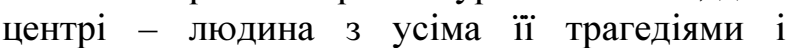
комедіями». Серед ключових понять, які сьогодні використовуються в науковій літературі щодо дизайн-проектування, ідея гуманізації середовища часто розглядається як 
синонім поняття людино-орієнтованого або інакше людино-центричного підходів (в зарубіжній науковій літературі - HumanCentered approach або People-Centered approach) до проектування. В той же час науковий підхід до розробки методології проектування вимагає чіткого визначення понять, якими оперує науковець - дизайнер.

Метою статті $€$ визначення сутності поняття людино-орієнтованого підходу в дизайні середовища в його сучасному розумінні і оцінка практики його впровадження в навчальний процес.

Основна частина. Витоки терміну «людино-орієнтований підхід» («людиноцентричний підхід») слід шукати в сфері започаткування i розвитку $(40-70$ роки минулого століття) недирективної або клієнтоцентрованої психотерапії. Людиноорієнтований підхід отримав надзвичайне поширення в 60-70-ті роки XX ст., справивши вагомий вплив на всю область психотерапевтичної і консультаційної практики i ставши одним 3 джерел гуманістичної психології (одного 3 напрямів сучасної психологічної науки, що виник на початку 60-х років в США). Її основоположниками i визнаними лідерами вважаються Карл Роджерс, а також Абрахам Маслоу [5]. Одним 3 основних наукових постулатів теорії К. Роджерса є: поняття про три «необхідні i достатні умови» міжособистісного спілкування 3 пацієнтом, що сприяють особистісному розвитку i забезпечують конструктивні особистісні зміни («безумовне позитивне прийняття іншої людини», «активне емпатичне слухання», «конгруентне самовираження в спілкуванні»); уявлення про стадії перебігу групового процесу психотерапії, що відповідають зазначеним соціально-особистісним умовам, а також їх закономірні терапевтичні результати. У центрі уваги теоретичних робіт К. Роджерса розвиток уявлень про емпатію, сутність яких, складається по-перше, в необхідності збереження психологічної дистанції між учасниками процесу емпатії або, іншими словами, відсутність в емпатії ототожнення між переживаннями емпатуємого і емпатуючого (на відміну від процесу емоційної ідентифікації), по-друге, наявність в емпатії співпереживання (яким би за своїм знаком і змістом не було переживання емпатуючого), а не просто емоційно позитивного ставлення (симпатіiі) емпатуючого до емпатуємого; по-третє, динамічний (процес, дія), а не статичний (стан, здатність) характер феномена емпатії [6].

Термін «орієнтований на людину дизайн» з'явився вже пізніше і заснований на терміні «орієнтований на користувача дизайн», що пов'язаний з роботами дослідної лабораторії Дональда Нормана в Каліфорнійському університеті в Сан-Дієго в 1980-х роках в області розробки інтерактивних комп'ютерних систем. Вперше у відношенні до дизайну термін був застосований в роботі [7]. Надалі у міжнародному стандарті ICO 9241-210: 2010 «Ергономіка взаємодії людина-система. Частина 210. Людино-орієнтоване проектування інтерактивних систем» було визначено шість характеристик процесу проектування інтерактивних комп'ютерних систем, орієнтованого на людину (людиноцентричного) [8]:

a) проектування має бути засноване на точному визначенні можливих користувачів, завдань і середовища;

b) користувачі повинні бути залучені в проектування і розробку;

с) для поліпшення проекту повинна бути виконана його людино-орієнтована оцінка;

d) вдосконалення проекту має бути ітеративним;

е) проект повинен враховувати досвід користувача;

f) в групу проектування повинні бути включені фахівці 3 навичками i знаннями в різних галузях.

Існує багатий досвід успішного використання наведеної стратегії в дизайнпроектуванні. Наразі компанії IKEA, Lego, Google, Facebook, Apple, що досягли певних досягнень у впровадженні своєї продукції, в більшій мірі фокусують свою увагу на оцінці емоційного зв'язку між своїми продуктами i споживачем, ніж на технології.

Прикладом стратегії проектування, що найбільш повно відображає людиноорієнтований підхід в дизайні сьогодні слід визнати стратегію дизайн-мислення (Design Thinking) широко тиражовану Школою Дизайну (D. School) університету м. Стенфорд (США) і детально описану в книзі Тіма Брауна - одного з розробників стратегії 
[9]. У центрі стратегії - робота в команді, як обов'язкова умова розвитку креативності особистості, залучення як замовників так і споживачів до роботи в команді, активне застосування найрізноманітніших методів соціологічних або маркетингових досліджень для досягнення емпатичного розуміння користувача i його потреб на стадії передпроектних досліджень, ітеративний процес пошуку рішень 3 використанням методів колективного пошуку ідей до тих пір, поки тестування прототипу користувачем не дасть позитивного результату.

Відповідно до вищесказаного, процес орієнтованого на людину проектування передбачає не тільки командну роботу, включення в процес проектування фахівців 3 навичками і знаннями в різних галузях, а й тестування прототипу (макет, ескізний проект тощо) користувачем.

При цьому одним із широко використовуваних інструментів людиноорієнтованого дизайну, який іноді називають емпатичним, $\epsilon$ створення вигаданих персонажів, що мають всі характеристики споживача (користувача) і включають крім усього іншого, демографічну інформацію про нього, необхідну для розробки продукту або послуги. При розробці дизайн-проекту враховуються особливості цього уявного персонажу $[4,10]$.

Отже сьогодні ми маємо справу 3 удосконаленими методами i стратегіями дизайн-проектування, орієнтованими на можливість емпатійного розуміння дизайнером вимог користувача 3 метою визначення необхідних якостей продукту дизайну. Такий вектор розвитку стратегій дизайну (людиноорієнтований дизайн) вимагає перегляду традиційних методів проектування в навчальному процесі, де студенти працюють, як правило, 3 віртуальним замовником $\mathrm{i}$ віртуальним споживачем. Зрозуміло, що магістерське дипломне проектування в дизайні середовища, яке, як правило, передбачає проведення студентом власних соціологічних або маркетингових досліджень для виявлення потреб користувача, є кроком до засвоєння технік людино-орієнтованого дизайну. Однак, як правило, оцінка концепції простору (тестування), спроектованого магістрантом об'єкта не проходить етап тестування споживачем, а статистична оцінка достовірності отриманих результатів соціологічних досліджень їх вподобань, проводиться не завжди коректно. У кращому випадку, є реальний замовник дизайн-проекту, який не завжди може оцінити відповідність якості дизайну потребам споживача. Оцінку теорії питання i результатів проектування дають члени комісії - професійні архітектори і дизайнери, які мають досвід проектування аналогічних об'єктів i оцінюють проблеми проекту 3 точки зору існуючих вимог до професійного проектування, що можливо розцінювати як тестування простору споживачем лише в певній мірі.

3 цієї точки зору, очевидно, окрім використання ігрових технологій (рольові ігри, в яких обговорення i тестування будь-якого студентського ескізного проекту або клаузури проводиться на навчальних заняттях студентською аудиторією за участю викладачакерівника проекту), корисним було б залучення студентів до проектування реальних об'єктів середовища, відпрацювання навиків командної роботи над проектом i оприлюднення отриманих результатів не тільки перед замовником, але i серед аудиторії споживачів для отримання відгуків (тестування). Наприклад, плакати презентації проектів інтер'єрів Музею води м. Києва 3 наочними комп'ютерними візуалізаціями, виконані студентами кафедри дизайну інтер'єру та меблів КНУТД, були розвішані в приміщенні музею. На етапі прийняття рішень в реальному проектуванні цих просторів, архітекторами були враховані не тільки захоплені відгуки директора музею, а й його відвідувачів (споживачів). Завдання персоналізації споживача продукту дизайну 3 виявленням потреб узагальнених персонажів, як один 3 етапів освоєння принципів емпатичного дизайну, на нашу думку, доцільно ввести в передпроектний аналіз хоча б на рівні окремих навчальних проектів, починаючи 3 бакалаврату.

Така практика сьогодні вже реалізується на кафедрі дизайну інтер'єру i меблів факультету дизайну КНУТД, де в курсі засвоєння дисципліни «Передпроектний i проектний аналіз в дизайні (за видами дизайну)» студенти створюють узагальнені образи відвідувачів громадських просторів різного функціонального призначення, їх поведінкові сценарії на підставі спостережень і 
бесід з метою подальшого використання цієї інформації в тематизації проектів. Практика показала, що виконання таких завдань, як правило, сприймається студентами 3 великою зацікавленістю i ентузіазмом, підвищує їx інтерес до професії, стимулює розвиток творчих здібностей.

Висновки.

Людино-орієнтований підхід в дизайні середовища слід розглядати не як абстрактне поняття гуманізації простору в практиці дизайн-проектування, а як стратегію або методику дизайну, яка передбачає наявність певних етапів у процесі проектування. Сучасна орієнтація навчального процесу на розвиток компетентностей випускників вишів відповідно до потреб ринку, вимагає адаптації навчального процесу до затребуваних на ринку стратегій.

Звідси необхідність апробації в навчальному процесі як окремих етапів людино-орієнтованого підходу (наприклад, стадії емпатії - глибокого вживання в роль споживача, що неможливо без ретельного вивчення контексту, певних емоційних зусиль, розвиненої уяви; персоналізації споживача), так і варіантів стратегії в повному обсязі, наприклад, під час навчальної практики або в дипломному проектуванні.

\section{Література}

1. Ковешникова Н. А. Актуальные проблемы дизайн-образования в контексте современной теории и практики дизайна / Н. А. Ковешникова // Вестник ТГУ. - 2011. - №4 (96). - С. 151-155.

2. Зеленая книга. Промышленный дизайн / Под редакцией В.Н. Княгинина. - СПб.: Фонд «Центр стратегических разработок «СевероЗапад», 2012. - 65 с.

3. Антонова О.С. Сутність поняття креативності: проблеми та пошуки // Теоретичні і прикладні аспекти розвитку креативної освіти у вищій школі: монографія / за ред. О.А. Дубасенюк. - Житомир: Вид-во ЖДУ ім. І.Франка, 2012. - С. 14-41.

4. Сафронова О. О. Особливості методики design thinking, як сучасної стратегії проектування в контексті дизайну середовища / О. О. Сафронова // Теорія і практика дизайну. Технічна естетика. 2017. - Вип. 13. - С. 180-193.

5. Карягина Т. Д. Откуда в психотерапии эмпатия: К. Роджерс и его психоаналитические предшественники и последователи / Т. Д. Карягина // Консультативная психология и психотерапия. 2012. - № 1. - C. 8-31.

6. Rogers Carl R. and Ruth C. Sanford. ClientCentered Psychotherapy. In Comprehensive Textbook of Psychiatry, V. Ed. H. I. Kaplan and B. J. Sadock. Baltimore: Williams and Wilkins, 1989.

7. Roy D. Pea. User Centered System Design: New Perspectives on Human-Computer Interaction // Journal educational computing research. - 1987. 3(1). - P.129-134.

8. ISO 9241-210:2010 Ergonomics of humansystem interaction - Part 210: Human-centred design for interactive systems, IDT.

9. Браун Т. Дизайн-мышление: от разработки нових продуктов до проек-тирования бизнесмоделей / Тим Браун. - Москва: Манн, Иванов и Фербер, 2012. - 175 с.

10. Михеева М.М. Методическое указание по курсу «История и методология дизайнпроектирования» / М.М. Михеева. - М.: МГТУ им. Н.Э. Баумана, 2015. - 104 с.

\section{References}

1. Koveshnikova, N. A. (2011). Aktual'nye problemy dizayn-obrazovaniya $\mathrm{v}$ kontekste sovremennoy teorii i praktiki dizayna [Actual problems of design education in the context of modern theory and practice of design]. Vestnik TGU - Bulletin of Tomsk State University, 96, 151-155 [in Russian].

2. Knyaginina, V. (Eds.) (2012). Zelenaya kniga. Promyshlennyy dizayn [The Green Book. Industrial Design]. SPb.: Fond «Tsentr strategicheskikh razrabotok «Severo-Zapad» [in Russian].

3. Antonova, O.Ie. (2012). Sutnist poniattia kreatyvnosti: problemy ta poshuky [The essence of the concept of creativity: problems and searches]. Teoretychni $i$ prykladni aspekty rozvytku kreatyvnoi osvity $u$ vyshchii shkoli: monohrafiia - Theoretical and applied aspects of the development of creative education in higher education: monograph. Dubaseniuk O.A. (Ed.). Zhytomyr: Vyd-vo ZhDU im. I. Franka, 14-41 [in Russian].

4. Safronova, O. O. (2017). Osoblyvosti metodyky design thinking, yak suchasnoi stratehii proektuvannia $\mathrm{V}$ konteksti dyzainu seredovyshcha [Features of the design thinking method as a contemporary design strategy in the context of the design environment]. Teoriia $i$ praktyka dyzainu. Tekhnichna estetyka - Theory and practice of design. Technical Aesthetics, 13, 180-193 [in Ukraine].

5. Karyagina, T. D. (2012). Otkuda v psikhoterapii empatiya: K. Rodzhers i ego psikhoanaliticheskie predshestvenniki i posledovateli [Where in psychotherapy empathy: K. Rogers and his psychoanalytic predecessors and followers]. Konsul'tativnaya psikhologiya $i$ psikhoterapiya Advisory psychology and psychotherapy, 1, 8-31 [in Russian].

6. Rogers, Carl R., and Ruth, C. Sanford. (1989) Client-Centered Psychotherapy. In Comprehensive Textbook of Psychiatry, V. Ed. H. I. Kaplan and B. J. Sadock. Baltimore: Williams and Wilkins [in English].

7. Roy D. (1987). Pea. User Centered System 
Design: New Perspectives on Human-Computer Interaction. Journal educational computing research, 3 (1), 129-134 [in English].

8. ISO 9241-210:2010 «Ergonomics of humansystem interaction - Part 210: Human-centred design for interactive systems», IDT. [in English].

9. Braun, T. (2012). Dizayn-myshlenie: ot razrabotki novikh produktov do proektirovaniya biznes-

\section{ВНЕДРЕНИЕ В УЧЕБНЫЙ ПРОЦЕСС ПРИНЦИПОВ ЧЕЛОВЕКО- ОРИЕНТИРОВАННОГО ПОДХОДА В ДИЗАЙНЕ АРХИТЕКТУРНОЙ СРЕДЫ САФРОНОВА Е.А.}

Киевский национальный университет технологий $и$ дизайна

Цель. Выявление сущности понятия человеко-ориентированного подхода в дизайне среды в его современном понимании и оценка практики его внедрения в учебный процесс.

Методика. Использованы методы: литературно-системного анализа научных публикаций по тематике исследования; сравнительного анализа современных методик и методов дизайн-проектирования; опыта внедрения стратегий человеко-ориентированного подхода в учебный процесс

Результаты. Проведен гносеоло-гический анализ истоков человеко-ориентированного подхода в дизайне, определено понятие современных стратегий человеко ориентированного дизайна в проектировании среды, даны рекомендации по внедрению стратегий человеко-ориентированного подхода в учебный процесс.

Научная новизна. Впервые понятие человеко-ориентированного подхода в дизайне среды рассматривается как стратегия дизайна, которая имеет характерные признаки и этапы.

Практическая значимость. Представ-лены предложения по эффективному внедрению методов стратегии человеко-ориентированного дизайна в учебный процесс

\section{Ключевые}

слова:

человеко-

ориентированный подход, учебный прочесс, дизайн архитектурной среды, дизайн-мышление, человекоориентированный дизайн, эмпати-ческий дизайн. modeley [Design thinking: from designing new products to designing business models]. Moskow: Mann, Ivanov i Ferber [in Russian].

10. Mikheeva, M.M. (2015). Metodicheskoe $u$ kazanie po kursu Istoriya $i$ metodologiya dizaynproektirovaniya [Methodical course on the course History and methodology of design- designing]. Moskow: MGTU im. N.E. Baumana [in Russian].

IMPLEMENTATION IN THE EDUCATIONAL PROCESS OF PRINCIPLES OF THE HUMANCENTER APPROACH TO THE DESIGN OF ARCHITECTURAL ENVIRONMENT SAFRONOVA O.O.

Kiev National University of Technologies and Design

Purpose. To identify the essence of the concept of a human-oriented approach in the environmental design in its modern understanding and to to evaluate the practice of its implementation in the learning process.

Methodology. The methods used: the literary-system analysis of scientific publications on the subject of research; a comparative analysis of modern techniques and methods of designengineering; experience in implementing humanoriented approaches in the learning process

Findings. An epistemological analysis of the origins of the human-oriented approach in design was carried out, the concept of modern humanoriented design strategies in the of the environmental design was defined, and recommendations for implementing the strategies of the human centered approach in the learning process.

Originality. The concept of a humanoriented approach in environmental design is considered as a design strategy that has specific features and stages for the first time.

The practical value. proposals were presented for the effective implementation of the methods of the strategy of human-oriented design in the educational process.

Keywords: human-oriented approach, environmental design, educational process, design thinking, human-oriented design, empathy design. 